\title{
PENERAPAN MODEL THREE PHASE TECHNIQUE DALAM MENINGKATKAN AKTIVITAS DAN HASIL BELAJAR MENULIS TEKS MONOLOG BERBENTUK DESCRIPTIVE/PROCEDURE
}

\author{
Paulina Christiani \\ SMP Negeri 2 Probolinggo, \\ Jalan dr. Moh. Saleh Kota Probolinggo
}

\begin{abstract}
Abstrak: Materi tentang menulis teks monolog berbentuk descriptive/procedure penting karena berkaitan dengan standar kompetensi menulis-mengungkapkan makna dalam teks tulis fungsional dan esai pendek sangat sederhana berbentuk descriptive dan procedure untuk berinteraksi dengan lingkungan terdekat. Pembelajaran bahasa Inggris di SMP bertujuan agar siswa mampu: 1) mengembangkan kompetensi berkomunikasi dalam bentuk lisan dan tulis untuk mencapai tingkat literasi functional; 2) memiliki kesadaran tentang hakikat dan pentingnya bahasa Inggris untuk meningkatkan daya saing bangsa dalam masyarakat global; 3) mengembangkan pemahaman siswa tentang keterkaitan antara bahasa dengan budaya. Penggunaan model TPT telah berhasil dilaksanakan untuk meningkatkan aktivitas dan hasil belajar dalam menulis teks monolog berbentuk descriptive/procedure pada siswa kelas VII.C SMP Negeri 2 Probolinggo. Hasil penelitian menunjukkan hasil belajar pada siklus II sebanyak 34 siswa atau 100\% mencapai KKM yang berarti mengalami peningkatan dibanding siklus I dimana siswa yang mencapai KKM hanya 29 siswa atau $85,29 \%$.
\end{abstract}

Kata Kunci: teks monolog descriptive/procedure, aktivitas, hasil belajar, three phase technique.

BNSP (2006:277) menyatakan bahwa bahasa Inggris merupakan alat untuk berkomunikasi secara lisan dan tulis. Berkomunikasi adalah cara memahami dan mengungkapkan informasi, pikiran, perasaan, mengembangkan ilmu pengetahuan, teknologi, serta budaya. Kemampuan berkomunikasi dengan bahasa Inggris dalam pengertian yang utuh adalah kemampuan berwacana, yakni kemampuan memahami dan menghasilkan teks lisan dan tulis yang direalisasikan dalam keterampilan reseptif dan keterampilan produktif. Keterampilan reseptif meliputi menyimak/mendengarkan (listening) dan membaca (reading), sedangkan keterampilan produktif meliputi berbicara (speaking) dan menulis (writing). Oleh karena itu, mata pelajaran bahasa Inggris diarahkan untuk mengembangkan keterampilan-keterampilan tersebut agar (lulusan) peserta didik mampu berkomunikasi dan berwacana dalam bahasa Inggris pada tingkat literasi tertentu.

Pembelajaran bahasa Inggris di SMP diharapkan dapat mencapai tingkat functional, yaitu berkomunikasi secara lisan dan tulis untuk menyelesaikan masalah sehari-hari. Oleh karena itu, pembelajaran bahasa Inggris di SMP bertujuan agar peserta didik mampu: 1) mengembangkan kompetensi 
berkomunikasi dalam bentuk lisan dan tulis untuk mencapai tingkat literasi functional; 2) memiliki kesadaran tentang hakikat dan pentingnya bahasa Inggris untuk meningkatkan daya saing bangsa dalam masyarakat global; serta 3) mengembangkan pemahaman peserta didik tentang keterkaitan antara bahasa dengan budaya (BNSP, 2006:278).

Kondisi di SMP Negeri 2 Kota Probolinggo pun kondisinya tidak jauh berbeda. Peneliti sebagai pengampu mata pelajaran bahasa Inggris merasa belum puas dengan apa yang diperoleh siswa. Dari sejumlah 34 (tiga puluh empat) siswa kelas VII.C, masih sekitar 58,82\% belum mencapai ketuntasan sebagaimana standar nilai bahasa Inggris yang ditetapkan dalam Kriteria Ketuntasan Minimal (75). Untuk itu selaku guru bahasa Inggris, peneliti merefleksi dan menganalisis mencari faktor-faktor pemicu rendahnya daya serap terhadap materi ajar bahasa Inggris tersebut.

Hasil refleksi dan analisis sementara ditengarai adanya kesulitan menulis teks monolog berbentuk descriptive/procedure. Karena itu hal yang perlu mendapatkan perhatian secara khusus adalah standar kompetensi menulis dalam mengungkapkan makna dalam teks tulis fungsional dan esai pendek sangat sederhana berbentuk descriptive dan procedure untuk berinteraksi dengan lingkungan terdekat.

Berangkat dari kondisi yang tergambar di atas itulah peneliti mencoba memperbaiki kemampuan siswa mempelajari materi menulis teks monolog berbentuk descriptive/procedure melalui model pembelajaran TPT (Three Phase Technique). Prediksinya adalah, melalui model pembelajaran ini siswa menjadi lebih aktif dan mengurangi kebosanan dalam belajar bahasa Inggris. Dengan situasi pembelajaran yang dibangun dalam pembelajaran TPT (Three Phase Technique) yakni hilangnya rasa bosan, timbulnya aktivitas, dan terbangunnya suasana pembelajaran nyaman, maka akan melecut keantuasiasan siswa dalam belajar bahasa Inggris, yang pada akhirnya keterampilan menulis teks monolog berbentuk descriptive/procedure siswa pun akan meningkat.

Three Phase Technique adalah teknik pembelajaran menggunakan 3 langkah, yaitu 1) kegiatan awal (pre activities), siswa diberi kegiatan yang menyenangkan agar tertarik dan mempunyai motivasi untuk belajar. Siswa diperkenalkan dengan topik yang akan dipelajari. Siswa menjawab pertanyaan tentang topik yang akan dipelajari. Kegiatan awal dilakukan mulai saat pembukaan pembelajaran. Guru melakukan kegiatan membuka pembelajaran seperti melakukan kegiatan untuk membangkitkan motivasi belajar, memancing pola pikir siswa sehingga siap dalam pembelajaran, dan memberikan pondasi yang akan dipakai dalam kegiatan inti; 2) kegiatan inti (main activities), siswa mendapat kegiatan yang berhubungan dengan materi inti. Siswa mempraktekkan skills yang menjadi tujuan pembelajaran. Kegiatan inti berisi kegiatan yang menunjang pencapaian indikator yang dibuat guru. Kegiatan inti ini bisa berisi teori dan praktek sesuai dengan tujuan pembelajaran; 3) dan kegiatan akhir (post activities), Siswa menyimpulkan kegiatan pembelajaran. Siswa mendapat feedback dan melakukan refleksi pembelajaran. Kegiatan akhir bukan hanya mengoreksi, tapi juga memberi feedback kemajuan siswa. Selain itu kegiatan akhir juga untuk evaluasi baik evaluasi dari guru kepada siswa, siswa kepada 
siswa, dan juga evaluasi diri. Apa yang dilakukan guru selama proses pembelajaran Three Phase Technique. Guru menjadi fasilitator dan memonitor kegiatan siswa. Di bagian akhir pembelajaran memberikan feedback dan menilai kemajuan pembelajaran

Sedangkan terkait aktivitas dan hasil belajar, menurut Rumini (1995) belajar sebagai proses atau aktivitas dipengaruhi beberapa faktor yang dapat diklasifikasikan menjadi: faktor yang berasal dari dalam diri orang yang belajar (internal) dan faktor dari luar (eksternal). Faktor internal dapat digolongkan menjadi 2, yaitu: 1) Faktor psikis, meliputi intelejensi, aurosal, motivasi, dan kepribadian. Intelejensi, yaitu kemampuan yang bersifat umum dapat abstraksi, memahami, mengingat, berbahasa untuk mengadakan penyesuaian terhadap suatu situasi/masalah. Aurosal, yaitu suatu peningkatan kesiapsiagaan dan ketegangan otot. Individu agar dapat belajar secara efisien harus dalam keadaan aurosal, yang artinya harus bangun, sadar, dan memperhatikan lingkungan secara tajam. Motivasi, yaitu kondisi psikis yang mendorong seseorang untuk melakukan sesuatu, yang berarti pula kondisi yang mendorong seseorang untuk belajar. Kepribadian, dapat mempengaruhi cara belajar siswa yang berpengaruh pula pada hasil belajar. 2) Faktor fisik, yakni kesehatan yang meliputi kondisi indera, organorgan tubuh dan anggota badan. Faktor eksternal, 1) Lingkungan sekitar, meliputi: lingkungan alam, sosial dan sosial Geografi. 2) Materi pelajaran. 3) Metode pembelajaran

Aktivitas belajar adalah aktivitas yang bersifat fisik maupun mental. Dalam proses belajar kedua aktivitas itu harus saling berkaitan. Lebih lanjut lagi Piaget menerangkan dalam buku Sardiman bahwa jika seorang anak berfikir tanpa berbuat sesuatu, berarti anak itu tidak berfikir (Sardiman, 2011:100). Hasil belajar pada hakikatnya merupakan pencapaian kompetensi-kompetensi yang mencakup aspek pengetahuan, keterampilan, sikap dan nilai-nilai yang diwujudkan dalam kebiasaan berpikir dan bertindak (Yulianto, 2010:8).

Hasil belajar adalah kemampuan yang diperoleh anak setelah melalui kegiatan belajar. Hasil belajar pada hakikatnya tersirat dalam tujuan pengajaran. Oleh sebab itu hasil belajar siswa di sekolah dipengaruhi oleh kemampuan siswa dan kualitas pengajaran. Hasil belajar siswa atau prestasi belajar siswa akan diperoleh setelah siswa menempuh proses atau pengalaman belajarnya (Winataputra, 2001:16). Penilaian hasil belajar adalah upaya mengumpulkan informasi untuk mengetahui seberapa jauh pengetahuan dan kemampuan telah dicapai oleh siswa (Winataputra, 2001:34).

Jadi, hasil belajar pada dasarnya merupakan kemampuan-kemampuan yang dimiliki siswa sebagai akibat dari pengalaman dari proses belajar siswa atau dengan kata lain hasil belajar dapat disebut sebagai perubahan tingkah laku siswa baik secara kognitif, afektif dan psikomotoris secara nyata setelah dilakukan proses pembelajaran yang sesuai..

\section{METODE}

\section{Jenis Penelitian}

Penelitian ini adalah Penelitian Tindakan Kelas (Classroom Action Research), karena itu rancangan penelitiannya mengikuti prosedur penelitian 
tindakan kelas. Menurut Suyanto (1997:5), penelitian tindakan kelas sebagai bentuk penelitian reflektif yang dilakukan oleh pendidik sendiri yang hasilnya dapat dimanfaatkan sebagai alat untuk pengembangan kurikulum, pengembangan sekolah, dan pengembangan keahlian mengajar.

Langkah-langkah yang diterapkan dalam PTK ini mengikuti model Kemmis and Taggart (1988), yang terdiri atas tahap (1) perencanaan yang merupakan upaya untuk memperbaiki kelemahan dalam proses pembelajaran, (2) pelaksanaan tindakan yaitu melaksanakan proses pembelajaran, (3) pengamatan/observasi untuk mengetahui kemampuan siswa dan untuk mengetahui sikap positif dan negatif siswa dalam kegiatan pembelajaran, dan (4) tahap refleksi (perenungan, pemikiran, dan evaluasi) di setiap siklusnya (siklus I dan II) untuk mengkaji, melihat, dan mempertimbangkan hasil atau dampak dari tindakan.

Penelitian tindakan kelas ini bertujuan untuk meningkatkan keterampilan siswa dalam membaca bahasa Inggris. Proses pelaksanaan penelitian dilaksanakan secara kolaborasi yang bersifat partisipan, artinya adanya keterlibatan secara aktif antara guru dan peneliti (guru Bahasa Inggris). Adapun penelitian ini dilaksanakan dalam tiga siklus, yang masing-masing siklus dilaksanakan dalam alokasi waktu 2 (dua) jam tatap muka.

\section{Instrumen Penelitian}

Instrumen yang digunakan dalam penelitian tindakan kelas ini meliputi, 1) Silabus, 2) Pelaksanaan Pembelajaran atau Rencana Pelaksanaan PTK, 3) Lembar Kerja Siswa, 4) Rubrik Pengamatan Siswa dan Model Pembelajaran, 5) Daftar Hadir Siswa, 6) Rubrik Pengamatan Guru, 7) Rubrik Wawancara Siswa, 8) Instrumen dan Soal Tes Tes Awal dan Akhir, dan 9) Analisis Data Hasil Penelitian Tindakan Kelas.

\section{Prosedur Penelitian}

\section{Tahap Perencanaan Tindakan}

Perencanaan tindakan dimulai dengan mempersiapkan RPP yang akan digunakan sebagai pedoman pelaksanaan pembelajaran kompetensi dasar 12.2 mengungkapkan makna dan langkah retorika dalam esai pendek sangat sederhana dengan menggunakan ragam bahasa tulis secara akurat, lancar dan berterima untuk berinteraksi dengan lingkungan terdekat dalam teks berbentuk descriptive/procedure melalui strategi pembelajaran kooperatif. Selain itu, peneliti guru juga menyusun lembar evaluasi untuk mengetahui hasil belajar siswa. Guru sebagai pengumpul data mempersiapkan daftar chek list pelaksanaan pembelajaran dan pencapaian indikator sebagai pedoman observasi, menyusun rubrik untuk menanyakan pendapat siswa mengenai pembelajaran yang telah dilaksanakan.

\section{Tahap Pelaksanaan Tindakan}

Pelaksana tindakan pembelajaran siklus I adalah guru bahasa Inggris, sedangkan pengamatan dan perekaman data dilakukan oleh guru mitra yang telah ditentukan. Sesuai dengan RPP yang sudah disusun, langkah-langkah 
pembelajaran yang akan dilakukan oleh guru mengacu pada langkah-langkah pembelajaran strategi pembelajaran kontekstual. Langkah-langkah tersebut adalah sebagai berikut:

Tabel 1: Sintak TPT (Three Phase Technique)

\begin{tabular}{|c|l|}
\hline No. & \multicolumn{1}{|c|}{ Three Phase Technique } \\
\hline 1. & $\begin{array}{l}\text { Pre activities. } \\
\text { Siswa diberi kegiatan yang menyenangkan agar tertarik dan mempunyai } \\
\text { motivasi untuk belajar. } \\
\text { Siswa diperkenalkan dengan topik yang akan dipelajari. } \\
\text { Siswa menjawab pertanyaan tentang topik yang akan dipelajari }\end{array}$ \\
\hline 2. & $\begin{array}{l}\text { Main activities. } \\
\text { Siswa mendapat kegiatan yang berhubungan dengan materi inti. } \\
\text { Siswa mempraktekkan skills yang menjadi tujuan pembelajaran. }\end{array}$ \\
\hline 3. & $\begin{array}{l}\text { Post activities. } \\
\text { Siswa menyimpulkan kegiatan pembelajaran. } \\
\text { Siswa mendapat feedback dan melakukan refleksi pembelajaran }\end{array}$ \\
\hline
\end{tabular}

\section{Tahap Pengamatan Tindakan}

Peneliti melakukan pengamatan dan perekaman terhadap aktivitas belajar siswa dan suasana pembelajaran yang terjadi di kelas. Semua aktivitas siswa direkam dengan cara mencatat apa yang dilakukannya, pengalaman apa yang diperolehnya, tanggapan apa yang disampaikannya berkaitan dengan aktivitas belajar dengan strategi pembelajaran kooperatif model TPT (Three Phase Technique).

\section{Tahap Refleksi Tindakan}

Setelah tindakan pembelajaran setiap siklus dilakukan kegiatan refleksi. Berdasarkan hasil refleksi tersebut dapat ditentukan apakah siklus pelaksanaan tindakan dapat diakhiri atau perlu dilanjutkan untuk siklus berikutnya. Dalam pelaksanaan refleksi tersebut, guru sebagai peneliti mendasarkan pada hasil pengamatan yang telah dilakukan berdasarkan indikator keberhasilan sebagai berikut: 1) Keaktifan siswa dalam proses belajar mengajar mencapai sekurang kurangnya $75 \%, 2$ ) Ketuntasan dalam menyelesaikan tugas sekurang kurangnya $75 \%$, dan 3) Ketuntasan hasil belajar siswa secara individu yang dinilai dari tes hasil belajar adalah sekurang kurangnya mencapai KKM 75.

\section{Indikator Keberhasilan Penelitian}

Indikator keberhasilan dalam penelitian tindakan kelas ini adalah jika minimal 75\% siswa kelas VII.C SMP Negeri 2 Probolinggo Tahun Pelajaran 2015/2016 dalam aktivitas dan hasil belajar menulis teks monolog berbentuk Descriptive/procedure akan meningkat mencapai KKM (75) jika diajar menggunakan model Three Phase Technique. 


\section{HASIL}

\section{Pengamatan Proses Belajar Siswa Siklus I dan II}

\section{Proses Pembelajaran Model TPT Siklus I dan II}

Hasil pengamatan pada siswa ketika melaksanakan model pembelajaran Three Phase Technique dapat dibagi dalam 3 (tiga) aspek sebagaimana tercantum pada tabel 2 di bawah ini:

Tabel 2 Indikator dan Skor Pengamatan Siswa (Siklus I dan II)

\begin{tabular}{|c|c|c|c|}
\hline NO & INDIKATOR & Siklus I & $\begin{array}{l}\text { Siklus } \\
\text { II }\end{array}$ \\
\hline \multirow[t]{2}{*}{ A } & Eksplorasi & \multirow[b]{2}{*}{2,15} & \multirow[b]{2}{*}{2,85} \\
\hline & $\begin{array}{l}\text { Pre Activities. } \\
\text { - Siswa diberi kegiatan yang menyenangkan agar tertarik dan } \\
\text { mempunyai motivasi untuk belajar. } \\
\text { - } \quad \text { Siswa diperkenalkan dengan topik yang akan dipelajari. } \\
\text { - Siswa menjawab pertanyaan tentang topik yang akan dipelajari }\end{array}$ & & \\
\hline \multirow[t]{2}{*}{ B } & Elaborasi & \multirow[b]{2}{*}{1,85} & \multirow[b]{2}{*}{2,71} \\
\hline & $\begin{array}{l}\text { Main Activities. } \\
\text { - Siswa mendapat kegiatan yang berhubungan dengan materi inti. } \\
\text { - Siswa mempraktekkan skills yang menjadi tujuan pembelajaran. }\end{array}$ & & \\
\hline \multirow[t]{4}{*}{$\mathrm{C}$} & Konfirmasi & \multirow[b]{2}{*}{1,94} & \multirow[b]{2}{*}{2,68} \\
\hline & $\begin{array}{l}\text { Post Activities. } \\
\text { - Siswa menyimpulkan kegiatan pembelajaran. } \\
\text { - Siswa mendapat feedback dan melakukan refleksi pembelajaran }\end{array}$ & & \\
\hline & Rerata & 5,94 & 8,24 \\
\hline & $\%$ Ketercapaian & $66,01 \%$ & $\begin{array}{c}91,50 \\
\%\end{array}$ \\
\hline
\end{tabular}

Pada tabel 2 dapat dijelaskan bahwa untuk siklus I, indikator pertama terdapat skor rerata indikator sebesar 2,15 (kategori Very Much) dimana siswa diberi kegiatan yang menyenangkan agar tertarik dan mempunyai motivasi untuk belajar. Pada indikator kedua pencapaian rata-rata sebesar 1,85 (kategori Much), dimana siswa mendapat kegiatan yang berhubungan dengan materi inti. Indikator ketiga pencapaian rata-rata sebesar 1,94 (kategori Much), dimana siswa menyimpulkan kegiatan pembelajaran, dan mendapat feedback dan melakukan refleksi pembelajaran. Persentase ketercapaian skor atau nilai rata-rata secara keseluruhan indikator pada kegiatan pembelajaran Simulasi adalah 66,01\% (kategori Much).

Untuk siklus II dapat dijelaskan bahwa untuk indikator pertama terdapat skor rerata indikator sebesar 2,85 (kategori Very Much) dimana siswa diberi kegiatan yang menyenangkan agar tertarik dan mempunyai motivasi untuk belajar. Pada indikator kedua pencapaian rata-rata sebesar 2,71 (kategori Very Much), dimana siswa mendapat kegiatan yang berhubungan dengan materi inti. Indikator 
ketiga pencapaian rata-rata sebesar 2,68 (kategori Very Much), dimana dimana siswa menyimpulkan kegiatan pembelajaran, dan mendapat feedback dan melakukan refleksi pembelajaran. Persentase ketercapaian skor atau nilai rata-rata secara keseluruhan indikator pada kegiatan pembelajaran Three Phase Technique adalah $91,50 \% \%$ (kategori Very Much)

\section{Proses Penugasan Dalam LKS Siklus I dan II}

Berdasarkan instrument tugas dalam LKS yang telah disusun untuk mengukur hasil tindakan penelitian maka dapat diuraikan sebagai berikut.

Tabel 3: Indikator dan Penilaian Tugas Dalam LKS

\begin{tabular}{|c|c|c|c|}
\hline \multirow{2}{*}{ No. } & Indikator Soal Tugas & \multicolumn{2}{|c|}{ Penilaian } \\
\cline { 3 - 4 } & Indikator Soal Tugas dalam LKS 1 (Pertemuan 1) & Siklus I & Siklus II \\
\hline 1. & Indikator Soal Tugas dalam LKS 2 (Pertemuan 2) & 74,97 & 84,74 \\
\hline 2. & Rerata Skor & 72,56 & 84,18 \\
\hline & Ryy & 73,76 & 84,46 \\
\hline
\end{tabular}

Pada tabel 3 dapat dijelaskan bahwa untuk siklus I, indikator pertama terdapat skor rerata sebesar 74,97 atau nilai rerata 3,00 dimana siswa mampu meraih ketercapaian 74,97\% dalam mengerjakan soal tugas dalam LKS Task 1-11. Pada indikator kedua pencapaian skor rata-rata sebesar 72,56 atau nilai rerata 2,90 dimana sebagian besar siswa mampu mencapai ketercapaian sebesar 72,56\% dalam mengerjakan tugas dalam LKS Task 12-21. Persentase ketercapaian skor atau nilai rata-rata secara keseluruhan indikator pada kegiatan penugasan dalam LKS adalah $73.76 \%$. Sedangkan siswa dalam mengerjakan tugas dalam LKS yang mencapai nilai kurang dari KKM (75) sebanyak 15 siswa atau 44,12\%), dan melampaui nilai KKM sebanyak 19 siswa $(55,88 \%)$.

Untuk siklus II dapat dijelaskan bahwa untuk indikator pertama terdapat skor rerata sebesar 84,74 atau nilai rerata 3,39 dimana siswa mampu meraih ketercapaian $84,74 \%$ dalam mengerjakan tugas dalam LKS Task 1-13. Pada indikator kedua pencapaian skor rata-rata sebesar 84,18 atau nilai rerata 3,37 dimana sebagian besar siswa mampu mengerjaka tugas dalam LKS Task 14-25 Persentase ketercapaian skor atau nilai rata-rata secara keseluruhan indikator pada kegiatan penugasan dalam LKS adalah 84,46\%. Sedangkan siswa dalam mengerjakan tugas dalam LKS mampu mencapai nilai melampaui nilai KKM sebanyak 34 siswa (100\%). Jadi secara keseluruhan siswa mampu mengerjakan tugas dalam LKS minimal mencapai nilai KKM sebanyak 34 siswa (100\%).

\section{Hasil Belajar Siklus I dan II}

\section{Hasil Pra Tes dan Tes Akhir Siklus I}

Hasil tes pra tindakan dapat diketahui bahwa dari ke 34 siswa, 14 siswa memperoleh nilai $>75$, sedangkan 20 siswa memperoleh nilai $<75$. Pada penilaian tes akhir tindakan siklus I dengan menggunakan 3 nomor soal uraian diperoleh 
sebanyak sebanyak 7 siswa $(20,59 \%)$ belum mencapai KKM $(<75)$, dan melampaui atau melebihi KKM (>75) sebanyak 27 siswa $(79,41 \%)$. Nilai terendah dalam tes hasil belajar ini adalah 65 dan nilai tertinggi sebesar 85 , sedangkan nilai rerata adalah 77,38 .

\section{Hasil Tes Akhir Siklus II}

Pada penilaian tes akhir tindakan siklus II dengan menggunakan 3 nomor soal uraian diperoleh sebanyak 34 siswa (100\%) mencapai melampaui atau melebihi KKM (>75). Nilai terendah dalam tes hasil belajar ini adalah 83 dan nilai tertinggi sebesar 100, sedangkan nilai rerata adalah 91,97.

Tabel 4: Hasil Tes Akhir Siklus I \& II

\begin{tabular}{|c|c|c|c|c|c|c|}
\hline No. & Kondisi & $\begin{array}{c}\text { Jumlah } \\
\text { Siswa } \\
<\text { KKM }\end{array}$ & $\begin{array}{c}\text { Jumlah } \\
\text { Siswa } \\
\text { KKM }\end{array}$ & $\begin{array}{c}\text { Nilai } \\
\text { Terendah }\end{array}$ & $\begin{array}{c}\text { Nilai } \\
\text { Tertinggi }\end{array}$ & $\begin{array}{c}\text { Nilai } \\
\text { Rerata }\end{array}$ \\
\hline 1. & Tes Akhir Siklus I & 7 & 27 & 65 & 85 & 77,38 \\
\hline 2. & Tes Akhir Siklus II & 0 & 34 & 83 & 100 & 91,97 \\
\hline & \multicolumn{2}{|c|}{$\%$ PeningkatanSiklus I - II } & $27,69 \%$ & $17,65 \%$ & $18,86 \%$ \\
\hline
\end{tabular}

\section{PEMBAHASAN}

\section{Proses Belajar Siswa}

Proses Pembelajaran Model TPT Siklus I dan II

Indikator penilaian sesuai sintaks model pembelajaran Three Phase Technique dalam pengamatan siswa menghasilkan beberapa hal sebagai berikut, pada siklus I nilai rerata sebesar 66,01, meningkat pada siklus II menjadi 91,50, nilai terendah yang diraih siswa pada siklus I adalah 44, meningkat menjadi 78 pada siklus II, nilai tertinggi pada siklus I adalah 78 dan meningkat pada siklus II menjadi 100.

Pada siklus I siswa sebanyak 8 siswa $(23,53 \%)$ dalam penilaian proses pembelajaran inti dengan menggunakan model Three Phase Technique telah melampaui nilai KKM (>75) dan siswa sebanyak 26 siswa $(76,47 \%)$ belum mencapai nilai KKM $(<75)$. Sedangkan pada siklus II sebanyak 34 siswa $(100 \%)$ siswa dalam penilaian proses pembelajaran inti dengan menggunakan model Three Phase Technique telah melampaui nilai KKM (>75).

\section{Proses Penugasan dalam LKS Siklus I dan II}

Proses penugasan dalam LKS dapat dijelaskan bahwa untuk masingmasing indikator adalah sebagai berikut: a) Indikator pertama dalam siklus I terdapat nilai rerata sebesar 3,00 dimana siswa mampu meraih ketercapaian $74,97 \%$ dalam mengerjakan tugas dalam LKS Task 1-11, sedangkan pada siklus II nilai rerata sebesar 3,39 dimana siswa mampu meraih ketercapaian 84,74\% dalam mengerjakan tugas dalam LKS Task 1-13, b) Indikator kedua dalam siklus I pencapaian nilai rata-rata sebesar 2,90 dimana sebagian besar siswa mampu mencapai ketercapaian sebesar 72,56\% dalam mengerjakan tugas dalam LKS Task 
12-21, sedangkan pada siklus II nilai rata-rata sebesar 3,37 dimana sebagian besar siswa mampu mencapai ketercapaian sebesar 84,18\% dalam mengerjakan tugas dalam LKS Task 14-25, c) Persentase ketercapaian dalam siklus I skor atau nilai rata-rata secara keseluruhan indikator pada kegiatan penugasan adalah $73,76 \%$, sedangkan pada siklus II skor atau nilai rata-rata secara keseluruhan indikator pada kegiatan penugasan dalam LKS adalah $84,46 \%$, d) Dalam siklus I siswa dalam mengerjakan tugas dalam LKS mampu mencapai nilai kurang dari KKM $(<75)$ sebanyak 15 siswa $(44,12 \%)$, dan melampaui nilai KKM sebanyak 19 siswa $(55,88 \%)$ sedangkan pada siklus II siswa dalam mengerjakan tugas dalam LKS mampu mencapai nilai melampaui nilai KKM sebanyak 34 siswa (100\%).

\section{Ketercapaian Proses Belajar Siswa}

Dalam siklus I proses tindakan meningkatkan aktivitas belajar menulis teks mnolog berbentuk descriptive/procedure melalui penerapan model TPT (Three Phase Technique), sebanyak 26 siswa (76,47\%) belum mencapai nilai KKM $(<75)$, dan melampaui nilai KKM (>75) sebanyak 8 siswa $(23,53 \%)$ siswa kelas VII.C SMP Negeri 2 Probolinggo Tahun Pelajaran 2015-2016, sedangkan pada siklus II sebanyak 34 siswa (100\%) melampaui nilai KKM (>75) siswa kelas VII.C SMP Negeri 2 Probolinggo Tahun Pelajaran 2015-2016.

\section{Hasil Belajar Siswa}

Untuk hasil tindakan meningkatkan aktivitas belajar menulis teks monolog berbentuk descriptive/procedure pada siswa kelas VII C SMP Negeri 2 Probolinggo Tahun Pelajaran 2015/2016 dapat diuraikan sebagai berikut:

Hasil tes akhir akhir tindakan dengan menggunakan 3 nomor soal uraian dapat diketahui bahwa: a) Siklus I terdapat 7 (tujuh) siswa yang memperoleh nilai yang kurang dari KKM $(<75)$, b) Sebanyak 27 (dua puluh tujuh) siswa memperoleh nilai melebihi KKM (>75) pada siklus I, sedangkan pada siklus II sebanyak 34 (tiga puluh empat) siswa (100\%) melampaui atau melebihi KKM $(>75)$, c) Nilai terendah dalam tes tindakan siklus I ini adalah 65, sedangkan pada siklus II nilai terendah dalam tes akhir tindakan ini adalah 83, d) Nilai tertinggi dalam tes tindakan siklus I sebesar 85, sedangkan pada siklus II nilai tertinggi dalam tes akhir tindakan sebesar 100, e) Nilai rerata dalam tes tindakan siklus I adalah 77,38, sedangkan pada siklus II nilai rerata dalam tes akhir tindakan adalah 91,97, f) Jadi pada siklus I secara keseluruhan siswa mampu mencapai dan melampaui nilai KKM sebanyak 27 siswa $(79,41 \%)$ dan memperoleh nilai kurang dari KKM sebanyak 7 siswa $(20,59 \%)$, sedangkan pada siklus II nilai secara keseluruhan siswa mampu mencapai dan melampaui nilai KKM sebanyak 34 siswa $(100 \%)$.

\section{Ketercapaian Hasil Tindakan}

Berdasarkan hasil rekapitulasi penilaian tes akhir tindakan siklus I dan akhir tindakan siklus II dapat dijelaskan bahwa seluruh siswa mengalami peningkatan signifikan yaitu peningkatan dari hasil tes akhir tindakan siklus I ke akhir tindakan siklus II secara individu mencapai 6,25\% hingga 35,14\%, dengan 
rerata peningkatan mencapai 19,09\%. Dalam hasil tindakan meningkatkan aktivitas belajar menulis teks mnolog berbentuk descriptive/ procedure, sebanyak 34 siswa (100\%) memperoleh nilai melampaui KKM siswa kelas VII.C SMP Negeri 2 Probolinggo Tahun Pelajaran 2015-2016 mencapai KKM (75).

\section{KESIMPULAN}

Adapun kesimpulan dari penelitian ini adalah: (1) Dalam siklus I aktivitas tindakan meningkatkan aktivitas belajar menulis teks mnolog berbentuk descriptive/ procedure melalui penerapan strategi pembelajaran kooperatif model Three Phase Technique (TPT) sebanyak 7 siswa (20,59\%) memperoleh nilai mencapai dan melampaui KKM dan memperoleh nilai kurang dari KKM sebanyak 27 siswa $(79,41 \%)$ siswa kelas VII.C SMP Negeri 2 Probolinggo Tahun Pelajaran 2015-2016 mencapai KKM (75) baik untuk aktivitas pembelajaran inti maupun penugasan. (2) Dalam Siklus II aktivitas tindakan meningkatkan aktivitas belajar menulis teks mnolog berbentuk descriptive/ procedure melalui penerapan strategi pembelajaran kooperatif model Three Phase Technique (TPT) sebanyak 34 siswa (100\%) memperoleh nilai melampaui KKM) siswa kelas VII.C SMP Negeri 2 Probolinggo Tahun Pelajaran 2015-2016 mencapai KKM (75) baik untuk aktivitas pembelajaran inti maupun penugasan. (3) Hasil tindakan pada siklus I dalam meningkatkan aktivitas belajar menulis teks monolog berbentuk descriptive/procedure melalui penerapan strategi pembelajaran kooperatif model Three Phase Technique (TPT) sebanyak 27 siswa $(79,41 \%)$ memperoleh nilai melampaui KKM dan memperoleh nilai kurang dari KKM sebanyak 7 siswa $(20,59 \%)$ siswa kelas VII.C SMP Negeri 2 Probolinggo Tahun Pelajaran 20152016 mencapai KKM (75). (4) hasil tindakan pada siklus II meningkatkan aktivitas belajar menulis teks monolog berbentuk descriptive/procedure melalui penerapan strategi pembelajaran kooperatif model Three Phase Technique (TPT) sebanyak 34 siswa (100\%) memperoleh nilai melampaui KKM siswa kelas VII.C SMP Negeri 2 Probolinggo Tahun Pelajaran 2015-2016 mencapai KKM (75). (5) Maka aktivitas dan hasil pada siklus II mengalami peningkatan dibanding siklus I sehingga indikator keberhasilan penelitian dari penelitian tindakan kelas ini telah tercapai.

\section{SARAN}

Berdasarkan simpulan di atas diketahui bahwa belajar menulis teks monolog berbentuk descriptive/procedure telah berhasil dilaksanakan untuk meningkatkan aktivitas dan hasil belajar peserta didik dalam belajar menulis teks monolog berbentuk descriptive/procedure melalui penerapan strategi pembelajaran kooperatif model Three Phase Technique (TPT) pada siswa kelas VII.C SMP Negeri 2 Probolinggo. Secara umum, disarankan agar lebih mengoptimalkan penggunaan model Three Phase Technique (TPT) sebagai salah satu alternatif untuk meningkatkan aktivitas pembelajaran bahasa Inggris, khususnya tentang belajar menulis teks monolog berbentuk descriptive/procedure. 


\section{DAFTAR RUJUKAN}

Badan Standar Nasional Pendidikan, 2006. Standar Kompetensi dan Kompetensi Dasar Tingkat SMP/MTs dan SMPLB. Jakarta: BNSP.

Gullo, W. (2002). Strategi Belajar Mengajar. Jakarta: PT. Gramedia Widiasarana Indonesia.

Kemmis, S. dan Mc. Taggart, R. 1988. The Action Research Planner. Victoria Dearcin University Press.Dahar, R.W. 1989. Teori-teori Belajar. Jakarta: Erlangga.

Rumini, Sri. 1995. Psikologi Pendidikan. Yogyakarta: UPP IKIP Yogyakarta.

Sardiman. 2011. Interaksi dan Motivasi Belajar-Mengajar. Jakarta: Rajawali Pers.

Sudjana, Nana. 2005. Penilaian Hasil Proses Belajar Mengajar.Bandung: PT Remaja Rosdakarya.

Tyler, R. W. (1973). Basic Principles of Curriculum and Instruction. London: Lowe and Brydone (Printers) Ltd.

Yulianto, A. Rony., \& Dewi, Apriani Fr. 2010. Kesulitan Belajar Perpajakan dan Pengaruhnya terhadap Motivasi Belajar Mahasiswa Pendidikan Ekonomi Universitas Pancasakti Tegal. Tegal: Program Studi Pendidikan Ekonomi,FKIP, Universitas Pancasakti Tegal.

Winataputra, Udin S. 2001. Model-model Pembelajaran Inovatif. Jakarta Pusat: Direktorat Jenderal Pendidikan Tinggi Departemen Pendidikan Nasional. 